\title{
シンポジウム
}

\section{ヒト臨床検体を用いた研究がもたらす アレルギー性鼻炎の新規治療戦略}

\section{はじめに}

我々耳鼻咽喉科医が扱うアレルギー性鼻炎の新規治療 法を開発するためには，ヒト臨床検体を用いた基礎研究 は欠くことができない大事なステップである。耳鼻咽喉 科領域は比較的容易にボリュームのある鼻粘膜組織や扁 桃といった臨床検体が手に入ることから, 組織の直接解 析や, 初代培養によるin vitroの系での解析が可能であ る。ある疾患の病態を理解する上で, ヒューマンサンプ ルの解析からは多くの情報が得られ，その情報をもとに 研究を進めていくことができれば大変効率的である。本 稿では，アレルギー性鼻炎の病態における鼻粘膜上皮と 免疫細胞の役割に着目し, ヒト臨床検体を用いたアレル ギー性鼻炎に関するこれまでの我々の研究成果と今後の 展望について述べてみたい。

\section{アレルギー性鼻炎におけるエピイムノーム}

鼻咽腔の粘膜上皮は外界と生体内を隔てる物理的バリ アとしての役割だけではなく，生体防御の最前線とし て, 病原体に対する粘膜免疫において重要な役割を担っ ている。アレルギー性鼻炎をはじめとするアレルギー性 炎症の発症メカニズムに関しては近年, 研究が進み, 新 しい概念が次々と明らかになってきた。例えばThymic stromal lymphopoietin (TSLP), IL-25, IL-33といった 上皮産生サイトカインがアレルギー疾患の病態形成の マスタースイッチとして免疫細胞を制御していることが 知られるようになってから，上皮細胞の役割が注目され るようになった1)。免疫細胞においても，2 型自然リンパ 球（ILC2）や従来の 2 型ヘルパー T (Th2) 細胞と区別 され，IL-4を産生してB細胞・形質細胞からのIgEの産生 制御を行う濾胞ヘルパーT（follicular helper T; Tfh）細 胞が発見され，アレルギー性炎症への関与が指摘されて いる ${ }^{2,3)}$ 。さらにはT細胞などの免疫反応を制御する制御 性B (regulatory B; Breg) 細胞の存在も明らかとなった4)。

\author{
亀倉 隆太 \\ 札幌医科大学耳鼻咽喉科
}

このように新しいプレイヤーの登場とともに，上皮細胞 と免疫細胞のクロストーク, “エピイムノーム”がアレル ギー性炎症の病態形成に重要な役割を担っていることが わかってきた（図 1 )。この“エピイムノーム”をターゲッ トとした新しい治療薬が開発されれば, 従来の薬剤より もアレルギー性炎症をより上流で抑えることができ，よ り効果的な治療に繋がる可能性がある。

\section{上皮産生サイトカインとアレルギー性鼻炎}

\section{(1)TSLP}

TSLPは樹状細胞の機能調節に関与し, 上皮細胞が主 に産生するIL-7様サイトカインとして，気管支喘息やア トピー性皮膚炎といったアレルギー疾患の発症に関与し ていることが知られている ${ }^{5,6)}$ 。我々はこれまでに，アレ ルギー性鼻炎患者の鼻粘膜では, 正常鼻粘膜と比較して, TSLPの発現が増加していること, その一方で, TSLPが 培養ヒト鼻粘膜上皮細胞や樹状細胞の夕イト結合蛋白の 発現を増加させ, バリア機能を増加させることを報告し だ)。このことは, 鼻粘膜の恒常状態, つまり, 正常鼻粘 膜上皮またはアレルギー性鼻炎発症の初期のような上皮 構造が比較的保たれている段階では，TSLPが鼻粘膜上 皮自らと樹状細胞のタイト結合蛋白の発現を増強するこ とで，バリア機能を保持し，樹状細胞による選択的な抗 原の取り込みを助けている可能性を示唆しており, TSLP が粘膜上皮の恒常性の維持に働いているという過去の報 告8)支持していた。

(2)IL-25

IL-25は別名IL-17Eとも呼ばれ, IL-17ファミリーに属す るサイトカインであり，TSLPと同様に，局所における アレルギー性炎症の誘導や制御に関与するサイトカイン であると考えられている。これまでにアトピー性皮膚炎 患者のケラチノサイトや気管支喘息患者の気道上皮にお いて高発現していることが報告されている ${ }^{9)}$ 。我々の検 討でも，アレルギー性鼻炎の鼻粘膜では, IL-25 mRNA 


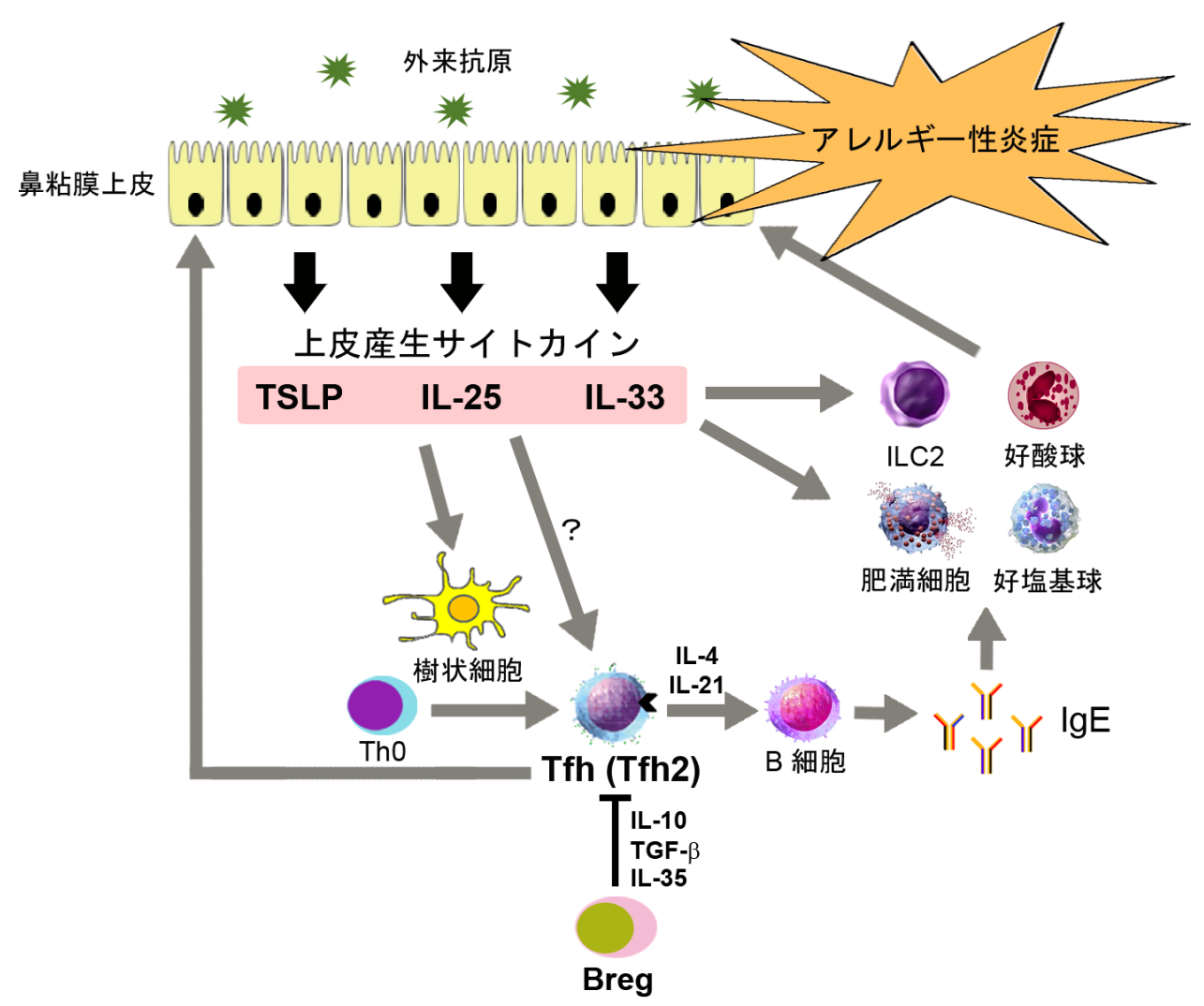

図 1 アレルギー性鼻炎の病態形成におけるエピイムノーム

の発現が増加しており，アレルギー性鼻炎患者の血清 IL-25值は健常者と比べて有意に上昇していた（未発表 データ)。

\section{(3)IL-33}

IL-33はIL-1様サイトカインに分類され, 特異的なレセ プターであるST2レセプターを介してTh2細胞などの免 疫細胞に作用し，アレルギー性炎症の発症に関与する ${ }^{10)}$ 。 最近のトピックとして，IL-33がILC2に作用して，自然免 疫系を介したアレルギー性炎症に関与していることが報 告された ${ }^{2)}$ このようにIL-33は自然免疫系, 獲得免疫系 の双方に作用するサイトカインと考えられている。実際 に, IL-33は気管支喘息患者の気道上皮, 気道平滑筋細胞, アトピー性皮膚炎患者の皮膚において高発現しているこ とが報告されている ${ }^{11}$ 。我々もアレルギー性鼻炎の鼻粘 膜では正常鼻粘膜と比較してIL-33の発現がmRNAレベ ルで増加していること, 免疫染色において, コントロー ル群でIL-33は上皮細胞の核にのみ発現しているのに対 して，アレルギー性鼻炎患者の鼻粘膜上皮では，核だけ ではなく細胞質にも強い発現を認めることを報告した ${ }^{12)}$ 。 このようにIL-33はアレルギー性鼻炎の病態形成にも強 く関与していると考えられる。

\section{2. 濾胞ヘルパー T (Tfh) 細胞}

Tfh細胞はCD4陽性ヘルパーT細胞サブセットの 1 つ であり，B細胞滤胞の胚中心や循環血液，局所に存在し， 抗原特異的な抗体産生を制御している ${ }^{13)}$ 。Tfh細胞から産 生されるIL-4はTh2細胞とは異なる制御機構で産生され ており，現在のところアレルギー病態において $\operatorname{IgE}$ 産生 を制御するへルパーT細胞はTfh細胞であると考えられ ている ${ }^{3)}$ 。中でも末梢血中に存在するTfh細胞（血液メモ リーTfh細胞）には 3 つのサブセット（Tfh1, Tfh2, Tfh17細胞）が存在すること，それぞれのサブセットが 特異的なサイトカインを産生し，B細胞を介した抗体産 生を制御することが知られている ${ }^{14)}$ 。最近我々は, アレ ルギー性鼻炎患者の血液中において, IL-4を産生し，B細 胞・形質細胞からの IgE産生を制御するTfh2細胞が増加 していること“Tfh2シフト”を世界で初めて報告した ${ }^{15)} 。$ Tfh2細胞は他のサブセットと違いIL-4を特異的に産生す ることから, 異常なTfh2シフトがアレルギー病態の形成 に関与していると考えられる。

\section{3. 制御性B (Breg) 細胞}

Breg細胞はIL-10, TGF- $\beta$, IL-35を産生することにより 
T細胞の免疫反応を抑制する働きをもつB細胞サブセッ トである。これまでに, Breg細胞を移入した多発性硬化 症モデルマウスでは, 疾患重症度が改善したとの報告, 関節リウマチ，SLE，気管支喘息患者に打ける末梢血中 のBreg細胞の数と機能の異常が報告されているが アレルギー疾患におけるBreg細胞の役割に関しては不 明な点が多く残されている。我々はアレルギー性鼻炎に おけるBreg細胞の役割を検討するために患者の末梢血 を解析したところ,アレルギー性鼻炎単独群と比較して, 気管支喘息を合併したアレルギー性鼻炎群では末梢血り ンパ球に占めるBreg細胞の割合が著減していた ${ }^{15)}$ 。これ らの結果から, Tfh2細胞とBreg細胞のバランスの破綻が アレルギー疾患の発症に関与し, Breg細胞はその増悪因 子である可能性が考えられた。

\section{4. エピイムノームをターゲットとした創薬の可能性}

近年の抗体製剤をはじめとする分子標的薬の進歩はめ ざましく，アレルギー疾患の治療に対しても新しい分子 標的薬が開発されている。

2009年に発売された抗IgE抗体（Omalizumab）は既に 気管支喘息治療薬として臨床現場で活躍している。アレ ルギー性鼻炎に対する効果も報告されているが，十分な エビデンスが得られていない上に，まだ日本では保険適 応となっていない。

2014年, TSLPを標的とする抗体製鼡（AMG157）のア レルギー性喘息患者に対する効果が報告された ${ }^{17}$ 。また 臨床研究の段階ではあるが, 抗TSLP抗体投与群ではプ ラセボ群と比較して，喘息反応を有意に軽減させたこと から，今後の製品化，アレルギー性鼻炎での適応が期待 される。

他にも現在，IL-25の受容体であるIL-17RAを標的とす る抗体製剤（Brodalumab）をはじめ，IL-4，IL-13，それ らの受容体に対する抗体の開発が進められている。

また，我々は，本稿でも取り上げたTfh細胞やBreg細 胞を新たなアレルギー疾患の標的細胞として注目してい る。Tfh2シフトを制御する因子, Breg細胞の数や機能を 制御する因子が発見されれば, Tfh2細胞への分化偏倚を 是正し, Breg細胞の数と機能を維持することによりアレ ルギー疾患の発症や増悪を抑えるという，新規の理論的 背景に基づいた治療法の開発が可能となるかもしれない。

\section{おわりに}

2014年，TSLPを標的とする抗体製剂のアレルギー性 喘息患者に対する効果が報告された。このような“エピイ ムノーム”をターゲットとした新しい治療薬が開発され
れば，従来の薬剤よりもアレルギー性炎症をより上流で 抑えることができ，より効果的な治療に繋がる可能性が あると思われる。TSLPがSoumelisらによって報告)され てから約12年，このような臨床応用に至る過程の出発点 はやはり，ヒト臨床検体を用いた基礎研究であった。耳 鼻咽喉科医は比較的容易に臨床検体を手に入れることが できるアドバンテージを持っていることから，耳鼻咽喉 科領域から臨床応用につながる研究を世界に発信できる 可能性を秘めている。

\section{参考文献}

1) Saenz SA, Taylor BC, Artis D : Welcome to the neighborhood: epithelial cell-derived cytokines license innate and adaptive immune responses at mucosal sites. Immunol Rev $2008 ; 226$ : 172-190.

2 ) Salimi M, Barlow JL, Saunders SP, et al : A role for IL-25 and IL-33-driven type-2 innate lymphoid cells in atopic dermatitis. J Exp Med $2013 ; 210$ : 29392950.

3 ）久保允人：抗体産生とTH2 - TFHの関係 臨床免 疫・アレルギー科 $2015 ; 63: 182-186$.

4) Rosser EC, Mauri C : Regulatory B cells: origin, phenotype, and function. Immunity $2015 ; 42: 607$ 612.

5 ) Soumelis V, Reche PA, Kanzler H, et al : Human epithelial cells trigger dendritic cell mediated allergic inflammation by producing TSLP. Nat Immunol $2002 ; 3: 673-680$.

6 ) Ying S, O’Connor B, Ratoff J, et al : Thymic stromal lymphopoietin expression is increased in asthmatic airways and correlates with expression of Th2attracting chemokines and disease severity. J Immunol $2005 ; 174: 8183-8190$.

7 ) Kamekura R, Kojima T, Koizumi J, et al : Thymic stromal lymphopoietin enhances tight-junction barrier function of human nasal epithelial cells. Cell Tissue Res 2009 ; 338 : 283-293.

8 ) Fritz JH, Le Bourhis L, Magalhaes JG, et al : Innate immune recognition at the epithelial barrier drives adaptive immunity: APCs take the back seat. Trends Immunol $2008 ; 29: 41-49$.

9) Wang YH, Angkasekwinai P, Lu N, et al : IL-25 augments type 2 immune responses by enhancing the expansion and functions of TSLP-DC-activated Th2 memory cells. J Exp Med 2007 ; 204 : 1837- 
1847.

10) Schmitz J, Owyang A, Oldham E, et al : IL-33, an interleukin-1-like cytokine that signals via the IL-1 receptor-related protein ST2 and induces T helper type 2-associated cytokines. Immunity $2005 ; 23$ : $479-490$.

11) Oboki K, Ohno T, Kajiwara N, et al : IL-33 and IL33 receptors in host defense and diseases. Allergol Int $2010 ; 59: 143-160$.

12) Kamekura R, Kojima T, Takano $K$, et al : The role of IL-33 and its receptor ST2 in human nasal epithelium with allergic rhinitis. Clin Exp Allergy $2012 ; 42: 218-228$.

13) Nurieva RI, Chung Y, Martinez GJ, et al : Bcl6 mediates the development of $\mathrm{T}$ follicular helper cells. Science 2009 ; 325 : 1001-1005.

14) Morita $R$, Schmitt $N$, Bentebibel SE, et al : Human blood $\mathrm{CXCR} 5^{+} \mathrm{CD} 4^{+} \mathrm{T}$ cells are counterparts of $\mathrm{T}$ follicular cells and contain specific subsets that differentially support antibody secretion. Immunity $2011 ; 34: 108-121$.

15) Kamekura R, Shigehara K, Miyajima S, et al : Alteration of circulating type 2 follicular helper $\mathrm{T}$ cells and regulatory $\mathrm{B}$ cells underlies the comorbid association of allergic rhinitis with bronchial asthma. Clin Immunol $2015 ; 158$ : 204-211.

16) van der Vlugt LE, Mlejnek E, Ozir-Fazalalikhan A, et al : $\mathrm{CD} 24^{\text {hi }} \mathrm{CD} 27^{+} \mathrm{B}$ cells from patients with allergic asthma have impaired regulatory activity in response to lipopolysaccharide. Clin Exp Allergy 2014 ; 44 : 517-528.

17) Gauvreau GM, O'Byrne PM, Boulet LP, et al : Effects of an anti-TSLP antibody on allergen-induced asthmatic responses. N Engl J Med 2014; 370 : 2102-2110. 